\title{
STRATEGI PENANAMAN NILAI-NILAI KEDISIPLINAN PESERTA DIDIK MELALUI ORGANISASI KEPRAMUKAAN UNTUK MEMBENTUK KARAKTER KEWARGANEGARAAN (STUDI DI SMP NEGERI 8 SURAKARTA TAHUN AJARAN 2018/2019)
}

Oleh :

\author{
Catur Wulandari \\ Prodi PPKn FKIP Universitas Sebelas Maret Surakarta \\ Email : caturwulandhari94@gmail.com \\ Erna Yuliandari \\ Universitas Sebelas Maret Surakarta \\ Email : ernayuliandari@staff.uns.ac.id \\ Triana Rejekiningsih \\ Universitas Sebelas Maret Surakarta \\ Email : triana_rizq@staff.uns.ac.id
}

\begin{abstract}
ABSTRAK
Tujuan Penelitian ini adalah untuk mengetahui: (1) strategi penanaman nilai-nilai kedisiplinan peserta didik melalui organisasi kepramukaan untuk membentuk karakter kewarganegaraan di SMP Negeri 8 Surakarta. (2) nilai-nilai kedisiplinan pesert didik setelah mengikuti kegiatan kepramukaan di SMP Negeri 8 Surakarta. (3) faktor pendukung dan penghambat dalam menanamkan nilai-nilai kedisiplinan melalui organisasi kepramukaan untuk membentuk karakter kewarganegaraan di SMP Negeri 8 Surakarta. Penelitian ini menggunakan metode deskriptif kualitatif dengan pendekatan studi kasus. Sumber data yang digunakan berupa informan, dokumen dan arsip serta tempat dan peristiwa.

Teknik Pengumpulan data yang digunakan untuk memperoleh dan menyusun data penelitian adalah dengan teknik pengamatan atau observasi, wawancara, dokumentasi dan angket. Teknik analisis yang digunakan adalah dengan analisis data model analisis interaktif.

Berdasarkan hasil penelitian dapat disimpulkan bahwa: (1) Strategi yang digunakan diantaranya strategi keteladanan dan pembiasaan, strategi dinamika kelompok, adanya kontrak pembelajaran di awal kegiatan pramuka, memberikan pengumuman kepada peserta didik supaya mempersiapkan kegiatan pramuka selanjutnya. (2) Nilai-nilai kedisiplinan peserta didik setelah mengikuti kegiatan pramuka berupa disiplin waktu, disiplin dalam berpakaian lengkap, disiplin dalam berbahasa dan disiplin dalam tata tertib. (3) Faktor penghambat dalam menanamkan nilai-nilai kedisiplinan diantaranya memiliki rasa minder untuk melakukan hal yang berkaitan dengan disiplin, tidak memiliki kemauan untuk disiplin, kurangnya
\end{abstract}


53 Catur Wulandari: strategi penanaman nilai-nilai kedisiplinan peserta ...

partisipasi dari guru lain, mayoritas dewan galang putri, susahnya mengatur peserta didik putra dan lingkungan pergaulan yang salah. Sedangkan faktor pendukungnya, yaitu adanya dukungan penuh dari orang tua untuk melakukan kegiatan pramuka, adanya tata tertib yang harus dipatuhi peserta didik, adanya pembentukan sikap dan keterampilan,sarana dan prasarana yang mendukung, adanya seleksi pramuka garuda, pihak pembina dari luar ikut berpartisipasi pada saat kegiatan berlangsung Kata Kunci: Penanaman, Nilai-Nilai Kedisiplinan, Karakter Kewarganegaraan

\begin{abstract}
The purpose of this study was to find out: (1) the strategy of instilling disciplinary values of students through scouting organizations to shape the character of citizenship in SMP Negeri 8 Surakarta. (2) disciplinary values of students after participating in scouting activities at SMP Negeri 8 Surakarta. (3) supporting and inhibiting factors in instilling the values of discipline through scouting organizations to shape the character of citizenship in SMP Negeri 8 Surakarta.

This research uses descriptive qualitative method with a case study approach. Data sources used in the form of informants, documents and archives as well as places and events.Data collection techniques used to obtain and compile research data are observation, observation, documentation and questionnaire techniques. The analysis technique used is the analysis of interactive analysis model data.

Based on the results of the study it can be concluded that: (1) The strategies used include exemplary and habituation strategies, group dynamics strategies, the existence of learning contracts at the beginning of scouting activities, giving announcements to students to prepare for the next scouting activities. (2) The values of student discipline after participating in scouting activities in the form of time discipline, discipline in fully dressed, discipline in language and discipline in discipline. (3) Inhibiting factors in instilling disciplinary values include having inferiority to do things related to discipline, not having the will to discipline, lack of participation from other teachers, the majority of female galang councils, the difficulty in managing male students and the wrong social environment. . While the supporting factors, namely the full support of parents to conduct scouting activities, the existence of rules that must be obeyed by students, the formation of attitudes and skills, supporting facilities and infrastructure, the selection of Boy Scouts, the guiding party from outside participated when activity in progress
\end{abstract}

Keywords: Inculcation, Disciplinary Values, Civic Disposition 


\section{PENDAHULUAN}

Pendidikan merupakan bagian dari proses pembangunan nasional. Seperti yang tertuang pada pembukaan Undang-Undang Dasar Negara Republik Indonesia Tahun 1945 alinea ke IV bahwa tujuan dari pembangunan nasional untuk melindungi segenap bangsa Indonesia dan seluruh tumpah darah Indonesia, memajukan kesejahteraan umum, mencerdaskan kehidupan bangsa dan ikut melaksanakan ketertiban dunia yang berdasarkan kemerdekaan, perdamaian abadi dan keadilan sosial. Hal tersebut diperkuat pula dengan tujuan pendidikan yang tercantum dalam Undang-Undang Nomor 20 tahun 2003 tentang Sistem Pendidikan Nasional bahwa pendidikan nasional berfungsi mengembangkan kemampuan dan membentuk watak serta peradaban bangsa yang bermartabat dalam rangka mencerdaskan kehidupan bangsa, bertujuan untuk berkembangnya potensi peserta didik agar menjadi manusia yang beriman dan bertaqwa kepada Tuhan Yang Maha Esa, berkahlak, mulia, sehat, berilmu, cakap, kreatif, mandiri dan menjadi warga negara yang demokratis serta tanggungjawab.

Berdasarkan uraian tersebut maka akan menghasilkan warga negara yang baik. Dalam dunia pendidikan yang berperan penting dalam membentuk warga negara yang baik adalah sekolah. Salah satu hal yang dapat dilakukan sekolah dalam membentuk warga negara yang baik adalah dengan penanaman nilai-nilai Kedisiplinan. Menurut Kemendiknas (2010:23), nilai-nilai kedisiplinan di Sekolah Menengah Pertama diantaranya :
1. Selalu tertib dalam melaksanakan tugas-tugas kebersihan sekolah

2. Tertib dalam berbahasa tulisan dan lisan

3. Patuh dalam menjalankan ketetapan-ketetapan organisasi peserta didik

4. Menaati aturan berbicara yang ditentukan dalam sebuah diskusi kelas

5. Tertib dalam menerapkan aturan penulisan untuk karya tulis.

Hal di atas senada dengan Sulhan (2011:38) yang mengemukakan bahwa indikator nilai-nilai kedisiplinan, diantaranya :

1. Membiasakan tepat waktu, tidak terlambat dalam melaksanakan aktivitas

2. Menghentikan bermain untuk melaksanakana kewajiban

3. Menaati peraturan yang berlaku

4. Menjalankan tugas sesuai jadwal yang telah ditentukan

5. Membiasakan untuk menata diri

6. Menerapkan disiplin dalam segala hal

7. Memiliki kesadaran tentang tugas dan tanggungjawab

8. Berfikir, bekera dan betindak dalam aturan.

Untuk mewujudkan tujuan tersebut maka bidang kesiswaan memiliki tugas yang utama yaitu membuat program kegiatan pembinaan dan pengembangan peserta didik. Salah satu wadah dalam 
kegiatan pembinaan dan pengembangan peserta didik di sekolah adalah kegiatan ekstrakulikuler, seperti Organisasi Kepramukaan. Keberadaan Organisasi Kepramukaan ini hampir menyeluruh terdapat di sekolahsekolah yang ada di daerah Surakarta, tidak terkecuali di SMP $\mathrm{N} 8$ Surakarta. Kegiatan Pramuka di SMP Negeri 8 Surakarta diikuti oleh seluruh warga sekolah khususnya kelas VIII dan kelas VII, namun untuk kelas VIII hukumnya dalam mengikuti kegiatan pramuka tidak wajib sedangkan untuk kelas VII kegiatan ini merupakan kegiatan ektrakurikuler yang wajib diikuti. Kelas VII yang mengikuti kegiatan ini sebanyak 254 peserta didik sedangkan untuk kelas VIII hanya Dewan Penggalang saja yang mengiktui kegiatan ini yang berjumlah 9 orang.

$$
\text { Kegiatan ekstrakurikuler }
$$

Pramuka merupakan salah satu pendidikan non formal yang memiliki peranan penting untuk menanamkan karakter kepada peserta didik. Kegiatan ini menjembatani kebutuhan peserta didik, seperti rasa akan nilai moral, kedisiplinan, kepatuhan, kesopanan, kecakapan berfikir dan sikap kemampuan serta kreativitas. Melalui partisipasinya dalam kegiatan ekstrakurikuler peserta didik dapat belajar dan mengembangkan kemampuan berkomunikasi, bekerja sama dengan orang lain, serta menemukan dan mengembangkan potensinya. Selain itu pula peserta didik dituntut untuk berkomunikasi dengan alam, karena sebagian dari kegiatan pramuka berada diluar sekolah, sehingga peserta didik akan berinteraksi secara langsung dengan alam supaya mampu menjaga kelestarian lingkungan hidup.

Adapun Kegiatan Gugus Depan 04.143/04.076 Pangkalan SMP Negeri 8 Surakarta diantaranya adalah Pembentukan regu dan serah terima jabatan Dewan Penggalang, Salam Pramuka, Sejarah Pramuka, Lambang Gerakan Pramuka, Pandu Dunia dan Lencana Kwarda Jawa Tengah, Sistem Isyarat Semaphore, Sistem Isyarat Morse, Sandi, Kompas, Penghayatan dan Pengalaman Tri Satya dan Dasa Dharma, Evaluasi SKU Penggalang Regu, KIM/Game dan Pelantikan Penggalang Regu. Untuk mewujudkan kegiatan tersebut diperlukan adanya pembiasan tingkah laku dan perilaku dalam kehidupan yang kemudian akan diaplikasikan dalam kehidupan sehari-hari.

$\begin{array}{cr}\text { Penanaman } & \text { nilai-nilai } \\ \text { disiplin melalui } & \text { kegiatan }\end{array}$ Kepramukaan ini diharapkan mampu mengubah perilaku disiplin siswa yang sesuai dengan tata peraturan dari organisasi tersebut sehingga mampu membentuk karakter kewarganegaraan peserta didik. Karakter kewarganegaraan ini merupakan bagian dari komponen pendidikan yang mempengaruhi aspek psikomotor dan aspek kognitif. Dalam setiap komponen tersebut mengandung arti bahwa warga negara yang memiliki pengetahuan kewarganegaraan akan menjadi warga negara yang cerdas. Warga negara yang memiliki keterampilan kewarganegaraan akan menjadi 
warga negara yang partisipatif, sedangkan warga negara yang memiliki karakter kewarganegaraan akan menjadi warga negara yang bertanggungjawab. Oleh karena itu, dalam hal meningkatkan kedisiplinan melalui kegiatan Pramuka harus mendapat dukungan penuh dari pihak sekolah, baik dari Pembina Pramuka maupun Dewan Penggalang.

Nilai-nilai kedisiplinan pada era saat ini semakin memudar dan tata tertib hanya sebagai simbol saja yang tidak mempunyai kekuatan untuk mengatur kehidupan sekolah. Berdasarkan observasi penulis selama melakukan kegiatan magang kependidikan ditemukan banyaknya siswa yang tidak mencerminkan nilai-nilai kedisiplinan, kemandirian serta kejujuran. Pelanggaran tata tertib sekolah ini tidak hanya terjadi pada saat kegiatan pramuka saja melainkan juga pada saat peserta didik berada dilingkungan sekolah, sehingga ada perbandingan antara peserta didik yang telah mengikuti kegiatan pramuka dan yang sebelum mengikuti kegiatan pramuka. Pelanggaran-pelanggaran tersebut diantaranya, masih adanya siswa yang datang terlambat, siswa kurang peduli terhadap lingkungan sehingga ketika melihat sampah justru diabaikan, saat hari jum'at masih ada beberapa siswa yang tidak menggunakan Seragam Pramuka Lengkap, kegaduhan dikelas seringkali terjadi dan semboyan
3S (Senyum, Sapa, Salam) tidak berjalan dengan baik.

Sedangkan pelanggaran yang dilakukan oleh peserta didik yang megikuti kegiatan pramuka, khususnya kelas VII SMP Negeri 8 Surakarta, diantaranya : Pada saat apel masih ditemukan siswa yang tidak tertib, seperti memainkan tongkat pramuka, masih adanya siswa yang tidak menggunakan Seragam Pramuka Lengkap, Dewan Penggalang melakukan kegiatan pramuka tanpa meminta izin kepada Pembina, masih adanya siswa yang tidak mengikuti kegiatan pramuka tanpa disertai dengan surat izin, tongkat pramuka seringkali digunakan untuk berkelahi hingga merusak fasilitas sekolah, masih adanya siswa yang tidak mengikuti PBB dengan alasan lelah dan membosankan. Hal ini relevan dengan Penelitian yang berjudul Implementasi Kegiatan Pramuka Sebagai Estrakurikuler Wajib Berdasarkan Kurikulum 2013 Dalam Upaya Pembinaan Karakter, yang menunjukkan hasil bahwa Pembina Pramuka belum bersertifikasi, belum ada transparasi dana, AD/ART Pramuka belum tersusun dengan baik, kurangnya fasilitas yang mendukung serta perizinan mengikuti kegiatan di jam efektif belum jelas, belum adanya Rencana Pelaksanaan Kegiatan program tahunan, semester , silabus. Selain iu belum adanya reward bagi peserta didik yang berperilaku baik ataupun berprestasi. 
Berdasarkan hasil yang diperoleh dari observasi kepada Pembina Pramuka, menunjukkan bahwa dari 254 peserta didik yang mengikuti kegiatan pramuka hanya sekitar 190 peserta didik yang sudah mampu menerapkan nilai-nilai kedisiplinan baik pada saat kegiatan pramuka berlangsung maupun pada saat peserta didik berada dilingkungan sekolah, seperti perubahan sikap pada peserta didik mulai terlihat pada saat menggunakan Seragam Pramuka Lengkap, peserta didik sudah memahami fungsi tongkat pramuka, bukti prosentrasi kehadiran peserta didik dalam mengikuti kegiatan pramuka semakin membaik serta sudah berjalannya semboyan $3 \mathrm{~S}$ (sapa, senyum, salam) kepada seluruh warga sekolah. Sedangkan 64 peserta didik lainnya masih belum mampu menanamkan nilai-nilai kedisiplinan ketika mengikuti kegiatan pramuka padahal pembekalan mengenai nilai-nilai kedisiplinan sudah disampaikan oleh Pembina Pramuka dan Dewan Penggalang. Dari 64 peserta didik tersebut ternyata memang seringkali melakukan pelanggaran, bahkan orang tua murid tersebut pernah mendapat panggilan dari pihak sekolah karena pelanggaran yang dilakukan oleh peserta didik tersebut. Pelanggaranpelanggaran yang seringkali dilakukan diantaranya adalah membolos kegiatan pramuka dengan sengaja, tidak pernah memperhatikan ketika Dewan Penggalang menyampaikan materi Pramuka dan tidak mematuhi pembayaran uang saku Pramuka.

Kajian tentang penanaman nilai-nilai kedisiplinan sudah terlebih dahulu dilakukan oleh peneliti lain, penelitian yang dilakukan oleh Ikhwanul Bekti Trian Putra (2017) tentang Penanaman Nilai-Nilai Karakter Melalui Ekstrakurikuler Pramuka di MAN 1 Yogyakarta yang menunjukkan bahwa proses penanaman nilai-nilai karakter melalui ekstrakurikuler Pramuka memperhatikan tahapan perencanaan, persiapan sampai dengan evaluasi yang di dalamnya memuat nilai-nilai karakter melalui kegiatan yang menarik, menantang dan rekreatif. Sedangkan penelitian relevan lainnya yang dilakukan oleh Santi Prasetiani (2013) tentang Pembentukan Sikap Disiplin Siswa Di Madrasah Ibtidaiyah Muhammadiyah Kaligondang Purbalingga Tahun Pelajaran 2013/2014 yang menunjukkan bahwa untuk membentuk sikap dengan pembiasaan perilaku dan Guru memberikan sanksi kepada siswa yang melanggar tata tertib sekolah berupa hukuman yang mendidik seperti hukuman pemberian tugas, melaporkan secara tertulis kepada orang tua siswa dan skoring.

Adapun penelitian relevan lainnya yang dilakukan oleh Ahmad Safe'i (2016) yang berjudul Peran Kegiatan Ekstrakurikuler Rohis Dalam Meningkatkan Kedisiplinan Siswa di MAN 2 Bandar Lampung yang mana dijelaskan bahwa peran Rohis dalam 
meningkatkan kedisiplinan, seperti disiplin dalam hal waktu, yaitu melalui kegiatan dzuhur berjamaah diawal waktu sholat dan sholat dhuha, Sedangkan disiplin dalam hal belajar yaitu melalui kegiatan pembelajaran Al-Qur'an dan selalu mengikuti kegiatan rutin yang diberikan oleh Pembina, Kemudian bertata krama melalui kegiatan liqo' dengan membekali pengetahuan serta nasihat kepada peserta didik. Kemudian dari sudut langkahlangkah pembinaan dalam meningkatkan kedisiplinan siswa, yaitu melalui pembiasaan, keteladanan yang baik seperti tepat waktu, berpakaian rapi, serta berkahlakul karimah kepada peserta didik, kemudian pada tahap pengawasan Pembina akan memberik teguran apabila menemui peserta didik yang tidak disiplin.

\section{METODE PENELITIAN}

Lokasi Penelitian di SMP Negeri 8 Surakarta yang berada di jalan HOS. Cokroaminoto No 51, Jebres, Kota Surakarta. Metode kualitatif digunakan untuk menganalisis objek yang akan diteliti berdasarkan kenyataan dilapangan. Sementara itu, pendekatan yang digunakan adalah diskriptif kualitatif. Penelitian ini memfokuskan pada strategi penanaman nilai-nilai kedisiplinan peserta didik melalui organisasi kepramukaan untuk membentuk karakter kewarganegaraan di SMP Negeri 8 Surakarta. Setiap penelitian membutuhkan data sebagai sumber informasi yang memberikan gambaran mengenai ada tidaknya masalah yang akan diteliti. Supaya memperoleh data penelitian dibutuhkan sumber data, berupa sumber data primer dan sumber data sekunder. Teknik pengambilan sampel, yaitu sampling purposive. Sampling purposive atau sampel bertujuan dilakukan dengan cara mengambil subjek bukan didasarkan atas strata, random atau daerah tetapi didasarkan atas adanya tujuan tertentu. Pihak-pihak yang terlibat langsung antara lain kepala sekolah, ketua koordinasi kegiatan pramuka, Guru PPKn , Pembina Pramuka dan Peserta Didik Kelas VII. Teknik pengumpulan data yang digunakan oleh peneliti berupa wawancara kepada kepala sekolah, ketua koordinasi organisasi kepramukaan,Guru PPKn, pembina pramuka, Dewan Galang kelas VIII dan peserta didik kelas VII. Observasi yang dilakukan berupa pengamatan kepada kegiatan-kegiatan penanaman nilai kedisiplinaan pada saat kegiatan pramuka berlangsung. studi dokumen yang diamati berupa tata tertib, program kerja kegiatan pramuka, berkas-berlas pramuka dan sebagainya serta angket mengenai penanaman nilai-nilai kedisiplinan peserta didik melalui organisasi kepramukaan untuk membentuk karakter kewarganegaraan. Teknik Uji Validitas data dalam penelitian menggunakan trianggulasi yang diartikan sebagai teknik pengumpulan data yang bersifat menggabungkan dari berbagai 
teknik pengumpulan data dan sumber data yang telah ada. Teknik analisis data yang digunakan berupa analisis data model interaktif yang terdiri dari tahap mereduksi data, menyajikan data dan menarik kesimpulan.

\section{HASIL PENELITIAN DAN PEMBAHASAN}

1. Strategi penanaman nilainilai kedisiplinan peserta didik melalui

kepramukaan membentuk organisasi untuk kewarganegaraan.

Keberhasilan seorang pendidik dalam membentuk karakter kewarganeganegaraan melalui kegiatan pramuka tentu diikuti dengan sebuah strategi. Strategi merupakan suatu upaya yang didalamnya terdapat langkah-langkah pelaksanaan mencapai sasaran yang telah ditetapkan. Tujuan dari adanya strategi ini adalah untuk mengajarkan siswa belajar atas kemauan dan kemampuan diri sendiri atau pembelajar mandiri (self-regulated learner).

(Suprihatiningrum, 2013:48). Strategi merupakan suatu siasat ataupun cara yang digunakan oleh sesoeorang dalam mencapai tujuan tertentu dengan menggunakan treatment sehingga mampu menghasilkan output yang berkualitas. Strategi penanaman nilainilai kedisiplinan ini sebenarnya dapat dilakukan melalui berbagai macam pengembangan diri ataupun melalui pembelajaran, namun disini peneliti melakukannya dengan pengembangan diri yang lingkupnya di luar kegiatan sekolah namun tetap ada dibawah kewenangan sekolah, sehingga jika di dalam pengembangan diri terjadi kecelakaan pihak sekolah akan turut membantu dan turun tangan. Strategi yang digunakan dalam upaya penanaman nilai-nilai kedisiplinan ini tentu yang berpengaruh pada perilaku peserta didik untuk menjadi pribadi yang tertib dan patuh terhadap segala peraturan yang ada di sekolah. Sebelum mengetahui strategi yang digunakan dalam menanamkan nilainilai kedisiplinan peserta didik melalui organisasi kepramukaan, maka alangkah baiknya peneliti menjabarkan pelanggaranpelanggaran yang seperti apa yang dikakukan oleh peserta didik kelas VII. Berikut adalah hasil wawancara peneliti kepada beberapa peserta didik kelas VII yang hampir seluruhnya pernah melakukan pelanggaran, seperti yang dikatakan oleh Aditya (Siswa kelas VII C) yang menyatakan bahwa "saya pernah mbak melanggar tidak menggunakan SPL" (Kutipan wawancara 2: Jum'at, 10 Mei 2019). Penuturan lain juga disampaikan oleh Andreas (Siswa kelas VII C) yang menyatakan bahwa "saya malah sering mbolos nggak ikut pramuka mbak, soalnya pramuka cuma seperti itu og kegiatannya mending main sama temen-temen" (Kutipan wawancara 2: Jum'at, 10 Mei 2019). Sama seperti siswa lainnya, EvelyN Joy (Siswa kelas VIIA) mengungkapkan bahwa "saya ikut pramuka tapi Cuma ikut-ikut aja mbak, datangnya aja kadang telat lha abis siang-siang panas mbak" (Kutipan wawancara 2: Jum'at, 10 Mei 2019). Keysa Omiken (Siswa kelas VIIA) juga menyamapaikan "saya justru pernah ada dibarisan terpisah dari temen-temen lainnya 
mbak karena pada saat apel saya ketahuan sedang bermain-main dengan teman saya" (Kutipan wawancara 2: Jum'at, 10 Mei 2019). Penelitian ini juga menggunakan metode observasi untuk mengetahui latar belakang guru dalam melakukan strategi penanaman nilai-nilai kedisiplinan peserta didik melalui organisasi kepramukaan. Observasi yang dilakukan oleh peneliti pada hari Jum'at, 03 Mei 2019 adalah saat kegiatan Apel.

Dari hasil observasi tersebut peneliti menemukan bahwa proses penanaman nilai-nilai kedisiplinan ini dilatar belakangi dengan adanya pelanggaran yang seringkali dilakukan oleh peserta didik kelas VII, diantaranya masih adanya siswa yang datang terlambat, siswa kurang peduli terhadap lingkungan sehingga ketika melihat sampah justru diabaikan, pada saat itu juga masih ada beberapa siswa yang tidak menggunakan Seragam Pramuka Lengkap, kegaduhan dikelas seringkali terjadi dan semboyan $3 \mathrm{~S}$ (Senyum, Sapa, Salam) tidak berjalan dengan baik Pada saat apel masih ditemukan siswa yang tidak tertib, seperti memainkan tongkat pramuka, masih adanya siswa yang tidak menggunakan Seragam Pramuka Lengkap, Dewan Penggalang melakukan kegiatan pramuka tanpa meminta izin kepada Pembina, masih adanya siswa yang tidak mengikuti kegiatan pramuka tanpa disertai dengan surat izin, tongkat pramuka seringkali digunakan untuk berkelahi hingga merusak fasilitas sekolah, masih adanya siswa yang tidak mengikuti PBB dengan alasan lelah dan membosankan. Jika kondisi tersebut dibiarkan tanpa adanya suatu tindakan yang tepat akan dikhawatirkan menimbulkan permasalan lainnya, baik di sekolah maupun di lingkungan masyarakat. Melihat usia mereka masih dalam tahap pencarian jati diri sehingga sifat kekanak-kanakan yang mereka miliki masih terbawa hingga memasuki sekolah menengah pertama. Oleh karena itu, baik pembina maupun dewan galang menemukan sebuah strategi yang digunakan dalam upaya menanamkan nilai-nilai kedisiplinan kepada peserta didik melalui organisasi kepramukaan. Strategi yang digunakanpun sangat sangat beragam. Berdasarkan hasil temuan deskripsi penelitian maka strategi penanaman nilai-nilai kedisiplinan peserta didik melalui organisasi kepramukaan untuk membentuk karakter kewarganegaraan diantaranya :

a) Strategi Pembiasaan dan keteladanan, Proses mendisiplinkan siswa merupakan suatu proses yang harus dilakukan secara bertahap. Apabila proses tersebut seringkali dilakukan maka seiring berjalannya waktu peserta didik akan memahami tentang pentingnya nilai disiplin, sehingga jika peserta didik tersebut melanggar peraturan maka secara tidak langsung mengetahui konsekuensi apa yang harus diterima.

b) Strategi Dinamika Kelompok, strategi melalui media kelompok masing-masing peserta didik mampu bertukar pikiran dan mencari pemecah masalah pada setiap agenda yang dilakukan sehingga pembina ataupun guru lain tidak memfokuskan pada hukuman melainkan jika terjadi pelanggaran melainkan melalui pendekatan. 
c) Adanya kontrak perjanjian di awal kegiatan pramuka, strategi ini merupakan mutlak hukumnya. Sehingga jika pada saat kegiatan pramuka berlangsung peserta didik diketahui melakukan pelanggaran maka saat itu juga peserta didik harus melaksanakan hukuman yang sudah disepakati pada saat kontrak perjanjian di awal kegiatan pramuka

d) Memberikan pengumuman kepada peserta didik supaya mempersiapkan kegiatan pramuka selanjutnya sehingga diharapkan tidak terhadi pelanggaran yang sama.

Berdasarkan uraian di atas, maka dapat di tarik kesimpulan bahwa strategi dalam menanamkan nilai-nilai kedisiplinan peserta didik kelas VII melalui organisasi kepramukaan untuk membentuk karakter kewarganegaraan melalui pembiasaan atau keteladanan, metode dinamika kelompok, adanya kontrak di awal kegiatan pramuka serta memberikan pengumuman yang tidak hanya lisan namun juga dalam bentuk pesan yang ditempel di papan pengumuman. Nilai kedisiplinan merupakan bagian dari karakter kewarganegaraam yaitu karakter privat yang merupakan karakter pribadi yang hanya dimiliki oleh orang itu sendiri, sehingga peserta didik memiliki kesadaran dengan sendirinya dalam melakukan kedisiplinan dan ia juga menyadari hasil dari menanamkan nilai kedisiplinan bagi dirinya seperti apa. Meskipun nilai-nilai yang terkandung dalam karakter privat ini merupakan nilai-nilai yang sederhana, namun jika nilai-nilai tersebut dilakukan secara terus menerus maka akan menjadi sebuah habits.

\section{Nilai-Nilai kedisiplinan peserta didik setelah mengikuti kegiatan pramuka di SMP Negeri 8 Surakarta}

Dalam lingkungan sekolah, kegiatan ekstrakulikuler Pramuka merupakan salah satu kegiatan yang wajib untuk diikuti oleh peserta didik kelas VII yang berjumlah 254 dan diikuti oleh 9 Dewan Galang kelas VIII. Sementara itu terdapat juga daftar kegiatan Gugus Depan 04.076/04.143 Pangkalan SMPN 8 Surakarta Semester Gasal Tahun 2018/2019, diantaranya Pembentukan Regu, Sistem Regu dan Serah Terima Jabatan Dewan Galang; Salam Pramuka; Sejarah Pramuka; Lambang Gerakan Pramuka, Pandu Dunia dan Lencana Kwarda Jawa Tengah; Lambang Negara, Sejarah Bendera Indonesia dan Lagu Kebangsaan; Sistem Isyarat Semaphore; Sistem Isyarat Morse; Sandi; Pionering; Kompas; Penghayatan dan Pengamalan Tri Satya dan Dasa Dharma; Evaluasi SKU Penggalang Ramu; KIM/Games; Pelantikan Penggalang Ramu (Sumber: Dokumen Sekolah Tahun 2018/2019) Untuk mengetahui perubahan yang terjadi pada nilai-nilai kedisiplinan peserta didik melalui organisasi kepramukaan, maka peneliti melakukan sebuah observasi yang dilakukan pada hari Jum'at, 10 Mei 2019. Hasil penelitian yang diperoleh oleh peneliti menunjukkan bahwa menunjukkan bahwa dari 254 peserta didik yang mengikuti kegiatan pramuka hanya sekitar 190 peserta didik yang sudah mampu menerapkan nilai-nilai kedisiplinan baik pada saat kegiatan pramuka berlangsung maupun pada saat peserta didik berada dilingkungan sekolah, seperti 
perubahan sikap pada peserta didik mulai terlihat pada saat menggunakan Seragam Pramuka Lengkap, peserta didik sudah memahami fungsi tongkat pramuka, bukti prosentrasi kehadiran peserta didik dalam mengikuti kegiatan pramuka semakin membaik serta sudah berjalannya semboyan 3S (sapa, senyum, salam) kepada seluruh warga sekolah. Sedangkan 64 peserta didik lainnya masih belum mampu menanamkan nilai-nilai kedisiplinan ketika mengikuti kegiatan pramuka padahal pembekalan mengenai nilai-nilai kedisiplinan sudah disampaikan oleh Pembina Pramuka dan Dewan Penggalang. Dari 64 peserta didik tersebut ternyata memang seringkali melakukan pelanggaran, bahkan orang tua murid tersebut pernah mendapat panggilan dari pihak sekolah karena pelanggaran yang dilakukan oleh peserta didik tersebut. Pelanggaran-pelanggaran yang seringkali dilakukan diantaranya adalah membolos kegiatan pramuka dengan sengaja, tidak pernah memperhatikan ketika Dewan Penggalang menyampaikan materi Pramuka dan tidak mematuhi pembayaran uang saku Pramuka. Berdasarkan hasil temuan observasi tesebut maka dapat disimpulkan bahwa strategi penanaman yang digunakan dapat dikatakan berhasil dalam menanamkan nilai-nilai kedisiplinan pada peserta didik kelas VII. Kemajuan peserta didik dalam menanamkan nilai-nilai-nilai kedisiplinan tersebut dapat diperkuat lagi dengan hasil angket yang dibagikan kepada peserta didik kelas VII pada saat kegiatan Pramuka berlngsung, dengan hasil sebagai berikut bahwa $67,5 \%$ peserta didik akan menanamkan nilai-nilai kedisiplinan pada diri sendiri dan $52,5 \%$ peserta didik akan mengaplikasikan nilai-nilai kedisiplinan pada kehidupan seharihari. Hal tersebut berarti segala aspek yang ditanamkan memiliki kemajuan yang sangat signifikan. Pada dasarnya kegiatan pramuka memang kegiatan diluar jam mata pelajaran yang menyenangkan sehingga dalam mangplikasikannya tidak hanya teori saja melainkan juga dengan praktel, terlebih kagi kegiatan ini bisa dilakukan didalam sekolag ataupun diluar sekolah. Salah satu hal yang membuat peserta didik tertarik dengan kegiatan pramuka karena pramuka menyenangkan, melalui kegiatan pramuka peserta manjadi lebih berani, berani dalam bertindak dan melakukan sesuatu. Setiap kegiatan pramuka selalu dibubuhi hal-hal yang berkaitan dengan nilinilai Pancasila, hal ini terbukti dengam hasil pernyataan "Selalu menjunjung tinggi nilai-nilai pancasila dalam setiap melakukan kegiatan Pramuka" dengan prosentase $55 \%$, selain itu juga terbukti dengan pernyataan "Menghargai lambang Negara dan Lagu Kebangsaan" dengan prosentasi $77,5 \%$. Indikator keberhasilan dalam menanamkan nilai-nilai kedisiplinan di antaranya adalah:

1. Manajemen waktu

Manajemen waktu merupakan suatu proses untuk mengatur jadwal seseorang sehingga waktu yang sudah diatur tidak mengkhawatirkan bertumburan dengan jadwal lain, Melalui manajemen waktu ini waktu peserta didik kelas VII mampu mengatur kegiatan apa saja yang akan dilakukan, contohnya saja pada saat 
Persami disitu peserta didik diberikan rundown acara yang sudah diatur jadwalnya oleh pembina sehingga segala aktivitas peserta didik saat Persami sudah jelas, kemudian pada saat lomba memasak juga diperlukan adanya manajemn waktu guna menyelesaikan plating, supaya hasil olahan dapat bagus maka melalui manajemen waktu anak dituntut untuk mensiasarti bagaiaman caranya agar tidak melebihi batas waktu yang telah ditentukna

2. Disipinan dalam berpakaian Lengkap

Memakai SPL merupakan salah satu hal yang wajib dilakukan di SMP Negeri 8 Surakarta, tidak hanya pada saat Pramuka saja melainkan pada saat setiap hari Jum'at baik peserta didik maupun guru atau karyawan dituntut untuk memakai Pramuka Lengkap, Selain itu pula SPL diterapkan untuk wajib dipakai ketika Gudep SMP Negeri 8 Surakarta menjuaari kegiatan pramuka, sehingga satu hari setelah kejuaraan seluruh watga sekolah dituntut untuk memakai SPL guna menghargai proses perjuangan yang dilakukan peserta didik dalam mengabdi pada kegiatan Pramuka,Selain SPL wajib digunakan pada hari Jum'at, SPL juga harus diterapkan pada saat peserta didik mngikuti kegiatan Pramuka seperti Apel, PBB, Persami Karena biasanya jik pada saat kegiatan tersebut SPL tidak lengkap maka akan diberikan hukuman

3. Disiplin dalam berbahasa

Melalui disiplin dalam berbahasa ini peserta didik dituntut untuk mampu menghargai satu sama lain pada saat sedang berdiskusi, karena pada agenda ini segala timing sudah diatur sehingga ketika pembina atau dewan galang sedang menjelaskan materi maka peserta didik harus memperhatikan, namun ketika waktu mereka sudah dialokasina kepada peserta didik maka hak sepenuhnya berada di peserta didik,

4. Disiplin dalam tata tertib

Tata tertib di sini merupakan tata tertib yang berlaku pada saat kegiatan pramuka yang tentunya tidak jauh beda dengan tata tertib sekolah, sehingga dengan dibuatnya tata tertib ini maka sudah ada poin-poin khusus jika peserta didik melanggar tata tertib tersebut.

Berdasarkan indikatorindikator di atas, maka dengan demikian disiplin sekolah bertujuan untuk memberi dukungan bagi terciptanya perilaku yang tidak menyimpang, mendorong siswa melakukan yang baik dan benar, membantu siswa memahami dan menyesuaikan diri dengan tuntutan lingkungannya dan menjauhi hal-hal yang dilarang oleh sekolah serta siswa belajar hidup dengan kebiasaankebiasaan yang baik dan bermanfaat baginya. Indikator tersebut telah membuktikan bahwa semakin hari tingkat kedisiplina peserta didik kelas VII semakin meningkat terbukti dengan berkurangnya peserta didik yang membolos tanpa ijin, selalu mengikuti kegiatan dengan gembira, SPL yang semakin rapi.Selain itu juga dalam kurun waktu 3 tahun berturutturut SMP Negeri 8 Surakarta menjuarai 3 kegiatan pramuka ditingkat kabupaten dan nasional, bahkan sekarang ini sedang mengajukan pramuka garuda, peserta didik semakin memberanikan diri 
dalam menampakkan bakatnya melalui pramuka.

\section{A. Faktor pendukung dan penghambat dalam menanamkan nilai-nilai kedisiplinan peserta didik melalui organisasi \\ kepramukaan untuk membentuk karakter kewarganegaraan di SMP Negeri 8 Surakarta.}

Faktor pendukung dan penghambat merupakan salah satu hal yang mampu dijadikan tolok ukur dalam keberhasilan sekolah untuk membentuk karakter kewarganegaraan di SMP Negeri 8 Surakarta . Berdasarkan hasil temuan yang dilakukan peneliti maka faktor penghambat dalam menanamkan nilai-nilai kedisiplinan peserta didik untuk membentuk karakter kewarganegaraan diantaranyaberupa adanya rasa minder atau malu jika melakukan kegiatan yang disiplin, tidak memiliki kemauan untuk melakukan hal yang berkaitan dengan disiplin, kurangnya partisipasi dari guru-guru lain dalam mengikuti kegiatan pramuka, mayoritas Dewan Galang Putri sehingga dalam proses ketegasan masih sangat kurang, Susahnya mengatur peserta didik khususnya laki-laki karena banyak yang menyepelakn kegiatan pramuka, Lingkungan pergaulan yang tidak benar. Sedangkan faktor pendukung dari prosesa penanaman nilai-nilai kedisiplinan peserta didik untuk membentuk karakter kewarganegaraan diantaranya adalah berupa adanya dukungan penuh dari orang tua untuk mengikuti kegiatan pramuka, adanya tata tertib yang harus dipatuhi peserta didik, adanya pembentukan sikap dan keterampilan, diberi penghargaan dan adanya seleksi pramuka garuda, adanya dukungan dari pihak sekolah, sarana dan prasarana yang mendukung kegiatan pramuka, adanya dukungan dari kedua orang tua, adanya seleksi pramuka garuda, Lingkungan keluarga yang mendukung akan kedisiplinan, Kerjasama antara orang tua dan guru, Pihak pembina dalam dan luar ikut berpartisipasi pada saat kegiatan berlangsung serta kontribusi dari dewan galang yang tanggap akan mendukung penanaman nilai-nilai kedisiplinan ini.

Berdasarkan uraian di atas, maka peneliti dapat menarik kesimpulan bahwa faktor penghambat dalam menanamkan nilai-nilai kedisiplinana peserta didik untuk membentuk karakter kewarganegaraan adalah kurangnya team work yang berpartisipasi dalam kegiatan pramuka, kehadiran pembina luar yang tidak selalu ikut dalam kegiatan pramuka, dukungan dari orang tua yang rendah serta mayoritas dari dewan galang diduduki oleh kaum puteri, sedangkan faktor pendukungnya adalah kegiatan pramuka ini mendapatkan dukungan penuh dari pihak sekolah dalam mencetak peserta didik yang berkarakter cerdas dan mulia, sarana dan prasarana yang memadai, adanya kerjasama antara guru dengan orang tua siswa supaya siswa mampu menjalankan segala kegiatan pramuka dengan khidmat.

\section{SIMPULAN DAN SARAN}

\section{A. Simpulan}

1. Strategi Penanaman nilainilai kedisiplinan peserta didik melalui organisasi 


\section{kepramukaan untuk membentuk karakter kewarganegaraan di SMP Negeri 8 Surakarta.}

Penanaman nilai-nilai kedisiplinan ke peserta didik dalam upaya membentuk karakter tentu tidaklah instan melainkan harus dengan proses yang bertahap, apalagi subyeknya adalah peserta didik kelas VII, dimana usia mereka adalah usia yang sangat rentan sekali untuk melakukan suatu pelanggaran. Oleh karena itu melalui organisasi kepramukaan ini diharapkan mampu meminimalisir nilai-nilai yang tidak disiplin menjadi disiplin kembali, melalui kegiatan pramuka peserta didik akan mendapatkan ilmu baik akademik maupun non akademik. Maka dari itu strategi yang digunakan oleh pembina dalam upaya menanamkan nilai-nilai kedisiplinan ini, dapat dijabarkan lebih rinci sebagai berikut, pertama melalui Pembiasaan atau keteladanan, karena proses mendisiplinkan siswa merupakan suatu proses yang harus dilakukan secara bertahap. Kedua, metode Dinamika Kelompok, strategi melalui media kelompok masingmasing peserta didik mampu bertukar pikiran dan mencari pemecah masalah pada setiap agenda yang dilakukan sehingga pembina ataupun guru lain tidak memfokuskan pada hukuman melainkan jika terjadi pelanggaran melainkan melalui pendekatan. Ketiga, Adanya kontrak perjanjian di awal kegiatan pramuka, strategi ini merupakan mutlak hukumnya. Keempat, Memberikan pengumuman kepada peserta didik supaya mempersiapkan kegiatan pramuka selanjutnya sehingga diharapkan tidak terhadi pelanggaran yang sama.

\section{Nilai-nilai Kedisiplinan Peserta didik setelah mengikuti kegiatan Pramuka di SMP Negeri 8 Surakarta.}

Nilai-nilai kedisiplinan merupakan suatu acuan yang digunakan oleh sekolah dalam mengukur tingkat kedisiplinan peserta didik, dengan adanya indikator-indikator yang ada akan memudahkan sekolah dalam memilah peserta didik yang taat peraturan dan tidak taat terhadap peraturan. indikator nilai-nilai kedisiplinan pada saat mengikuti kegiatan pramuka, diantaranya adalah:

a. Manajemen waktu

Manajemen waktu merupakan suatu proses untuk mengatur jadwal seseorang sehingga waktu yang sudah diatur tidak mengkhawatirkan bertumburan dengan jadwal lain, Melalui manajemen waktu ini waktu peserta didik kelas VII mampu mengatur kegiatan apa saja yang akan dilakukan

b. Disipinan dalam berpakaian Lengkap

Memakai SPL merupakan salah satu hal yang wajib dilakukan di SMP Negeri 8 Surakarta, tidak hanya pada saat Pramuka saja melainkan pada saat setiap hari Jum'at baik peserta didik maupun guru atau karyawan dituntut untuk memakai Pramuka Lengkap, Selain itu pula SPL diterapkan untuk wajib dipakai ketika Gudep SMP Negeri 8 Surakarta menjuaari kegiatan pramuka, sehingga satu hari setelah kejuaraan seluruh watga sekolah dituntut untuk 
memakai SPL guna menghargai proses perjuangan yang dilakukan peserta didik dalam mengabdi pada kegiatan Pramuka,Selain SPL wajib digunakan pada hari Jum'at, SPL juga harus diterapkan pada saat peserta didik mngikuti kegiatan Pramuka seperti Apel, PBB, Persami Karena biasanya jik pada saat kegiatan tersebut SPL tidak lengkap maka akan diberikan hukuman

c. Disiplin dalam berbahasa

Melalui disiplin dalam berbahasa ini peserta didik dituntut untuk mampu menghargai satu sama lain pada saat sedang berdiskusi, karena pada agenda ini segala timing sudah diatur sehingga ketika pembina atau dewan galang sedang menjelaskan materi maka peserta didik harus memperhatikan, namun ketika waktu mereka sudah dialokasina kepada peserta didik maka hak sepenuhnya berada di peserta didik,

3. Faktor Pendukung dan

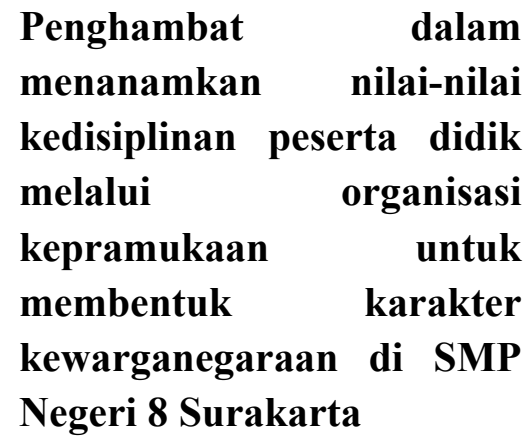

Faktor penghambat dalam menanamkan nilai-nilai kedisiplinan peserta didik melalui organisasi kepramukaan untuk membentuk karakter kewarganegaraan diantaranya: adanya rasa minder atau malu jika melakukan kegiatan yang disiplin, tidak memiliki kemauan untuk melakukan hal yang berkaitan dengan disiplin, kurangnya partisipasi dari guru-guru lain dalam mengikuti kegiatan pramuka, mayoritas Dewan
Galang Putri sehingga dalam proses ketegasan masih sangat kurang, Susahnya mengatur peserta didik khususnya laki-laki karena banyak yang menyepelakn kegiatan pramuka, Lingkungan pergaulan yang tidak benar. Sedangkan Faktor pendukung dalam menanamkan nilai-nilai kedisiplinan peserta didik melalui organisasi kepramukaan untuk membentuk karakter kewarganegaraan diantaranya: berupa adanya dukungan penuh dari orang tua untuk mengikuti kegiatan pramuka, adanya tata tertib yang harus dipatuhi peserta didik, adanya pembentukan sikap dan keterampilan, diberi penghargaan dan adanya seleksi pramuka garuda, adanya dukungan dari pihak sekolah, sarana dan prasarana yang mendukung kegiatan pramuka, adanya dukungan dari kedua orang tua, adanya seleksi pramuka garuda, Lingkungan keluarga yang mendukung akan kedisiplinan, Kerjasama antara orang tua dan guru, Pihak pembina dalam dan luar ikut berpartisipasi pada saat kegiatan berlangsung serta kontribusi dari dewan galang yang tanggap akan mendukung penanaman nilai-nilai kedisiplinan ini.

\section{B. SARAN}

1. Bagi Sekolah sebaiknya melakukan kontrak kerjasama terhadap pembina dari luar dalam membimbing kegiatan Pramuka, sehingga setiap pekan dari pihak Dewan Galang tidak merasa kekurangan pembina Pramuka

2. Bagi Guru sebaiknya ada kerjasama antara guru-guru yang tidak ber SK dalam kegiatan 
67 Catur Wulandari: strategi penanaman nilai-nilai kedisiplinan peserta ...

pramuka dengan guru-guru yang telah ber SK dalam kegiatan pramuka supaya beliau juga ikut memantau kegiatan Pramuka, sehingga kontribusi dari guru-guru lain dapat terlihat dalam upaya menanamkan nilai-nilai kedisiplinan pada peserta didik, Selain itu guru yang berstatuskan Pembina harus mampu mengevaluasi setiap kegiatan Pramuka sehingga kegiatan tersebut tidak monoton namun dapat berkembang secara kreatif dan inovatif .

3. Bagi Peserta Didik

a. Peserta didik dianjurkan untuk lebih memahami pentingnya kegiatan Pramuka, karena kegiatan dalam pramuka sangat banyak manfaatnya. Selain kita mendapatkan ilmu teoritis, peserta didik juga akan mendapatkan ilmu praktisnya sehingga peserta didik akan lebih memahami kegiatankegiatan yang dilakukan pembina karena langsung diberikan contoh kongkritnya.

b. Pada saat proses kegiatan berlangsung, beberapa peserta didik tidur di kelas, acuh tak acuh tidak memperhatikan pada saat pembina memberikan materi, berbicara sendiri dengan temannya. Oleh karena itu, peserta didik harus memperhatikan saat pembina memberikan materi, untuk mengurangi rasa ngantuk dapat dilakukan dengan cuci muka ke kamar mandi supaya dapat berkosentrasi terhadap materi yang disampaikan. 


\section{DAFTAR PUSTAKA}

AD/ART Gerakan Pramuka Munas Tahun 2013 Tentang Tujuan Gerakan Pramuka

Afrizal. 2015. Metode Penelitian Kualitatif: Sebuah Upaya Mendukung Penggunaan Penelitian Kualitatif dalam Berbagai Disiplin Ilmu. Jakarta: PT Rajagrafindo Persada.

Adisusilo, Sutarjo.2013. Pembelajaran Nilai Karakter :Kontrukstivisme dan VCT Sebagai Inovasi Pendekatan Pembelajaran Afektif. Jakarta:Rajawali

Press

Akdon.2011. Strategic Management For Educational Management (Manajemen Strategi Untuk Manajemen Pendidikan). Bandung: Alfabeta

Asrori,M. 2015. Perkembangan Peserta Didik : Pengembangan Kompetensi Pedagogis Guru. Yogyakarta: Media Akademi

Berkowits dan Bier.2006. What Work In Character Education: A Research-driven guide for educators.___ Character Education Partnership

Budimansyah, Dasim.2010.Penguatan Pendidikan Kewarganegaraan Untuk Membangun Karakter Bangsa. Bandung:Widya Aksara Press

Chasiyah,dkk. 2009. Perkembangan Peserta Didik. Surakarta:Yuma Pustaka

Darmadi. 2018. Guru Abad 21 "Perilaku dan Pesona Pribadi". :Guepedia

Desmita. 2012. Psikologi Perkembangan Peserta Didik: Panduan bagi Orang Tuadan Guru dalam Memahami Psikologi Anak Usia SD, SMP,

SMA. Bandung: Rosdakarya Offset

Elmubarok, Zaim.2009. Menumbuhkan Pendidikan Nilai.Bandung: Alfabeta

Emzir. 2014. Metodologi Penelitian Kualitatif Analisis Data.Jakarta: Rajawali Pers

Kementrian Pendidikan Nasional.2010. Pengembangan Pendidikan Budaya dan Karakter Bangsa. Jakarta: Kementrian Pendidikan Nasional

Lickona, Thomas. 2016. Educating for Character:How Our School Can Teach Respect and Responbility. Jakarta:Bumi Aksara

Ma'mur Asmani, Jamal. 2011. Buku Panduan Internalisasi Pendidikan Karakter di Sekolah. Yogyakarta:Diva Press

Mulyasa.2006. Manajemen Pendidikan Karakter. Jakarta:Bumi Aksara

Pattaro, C. 2016. Character Education: Themes and Researches. An academic Literature Review. Italian Journal of Sociology of Education, 8(1), 6-

30. Italian: Padova University Press. Diperoleh 30 Agustus 2019 dari http://www.iises.net/download/Soubory/soubory-puvodni/pp1020ijote V2N2.pdf

S.P Hasibuan, Malayu.2003. Organisasi dan Motivasi Dasar Peningkatan, Produktivitas. Jakarta:Bumi Aksara.

Saleh, Muwafik. 2012. Membangun Karakter dengan Hati Nurani:Pendidikan Karakter Untuk Generasi Bangsa. Jakarta : Erlangga 
69 Catur Wulandari: strategi penanaman nilai-nilai kedisiplinan peserta ...

Salusu, Jamsari. 2003. Otonomi Daerah dalam Negara Kesatuan Republik Indonesia. Jogjakarta: Pustaka Pelajar

Sugiyono.2015. Metode Penelitian Pendidikan :Pendekatan Kuantitatif, Kualitatif dan $R \& D$.Bandung:Alfabeta

Sulhan, Najib. 2011.Pengembangan Karakter Dan Budaya Bangsa . Surabaya: PT Jepe Press Media Utama

Supriadi, Oding. 2013. Perkembangan Peserta Didik. Yogyakarta: Kurnia Kalam Semesta

Supriyadi.2014. Strategi Belajar dan Mengajar. Yogyakarta:Jaya Ilmu

Triatna, Cepi. 2016. Perilaku Organisasi dalam Pendidikan.Bandung: PT Remaja Rosdakarya Offset

Winarno.2014. Pembelajaran Pendidikan Kewarganegaraan Isi, Strategi dan Penilaian. Jakarta: Bumi Aksara.

Zuriah, Nurul. 2015. Pendidikan Moral dan Budi Pekerti Dalam Perspektif Perubahan. Jakarta: Bumi Aksara.

Bekti TP,Ikhwanul.(2017). Penanaman Nilai-Nilai Karakter Melalui Ekstrakurikuler Pramuka di MAN 1 Yogyakarta. Jurnal. Di peroleh 09 Februari 2019 dari e- journal.ivet.ac.id.

Prasetiani, Santi. (2013). Pembentukan Sikap Disiplin Siswa di Madrasah Ibtidaiyah Muhammadiyah Kaligondang Purbalingga Tahun

Pelajaran 2013/2014. Skripsi. Diperoleh 09 Februari 2019 dari repository.iainpurwokerto.ac.id

Safe'i, Ahmad. (2016). Peran Kegiatan Ekstrakurikuler Rohis Dalam Meningkatkan Kedisiplinan Siswa di MAN 2 Bandar Lampung. Skripsi. Diperoleh 10 Februari 2019 dari repository.radenintan.ac.id

www.wikipedia.org diakses pada 09 Januari 2019 pukul 18.30.

http://pramuka.lk.ipb.ac.id/files/2012/11/Sejarah-Gerakan-Pramuka.pdf diakses pada 10 Januari 2019 pukul 16.00 .

http://pramuka.ulm.ac.id/wp-content/uploads/2017/08/AD-ART-GerakanPramuka-Munas-2013.pdf diakses pada 10 januari 2019 pukul 17.30

http://digilib.unimed.ac.id/1383/1/Pramuka\%20ekstrakurikuler\%20wajib\%20diF 20sekolah.pdf diakses pada 31 januari 2019 pukul 18.58

https://id.wikipedia.org/wiki/Gerakan_Pramuka_Indonesia) diakses pada 31 januari 2019 pukul 20.06)

Undang-Undang Dasar Republik Indonesia Tahun 1945.

Undang-Undang No 20 Tahun 2003 Tentang Sistem Pendidikan Nasional.

Undang-Undang No 12 Tahun 2010 Tentang Pramuka.

Permendiknas RI Nomor 22 Tahun 2006 Tentang Standar Isi Untuk Satuan Pendidikan Dasar dan Menengah 